\title{
Value of Admission HbAlc Level in Non-diabetic Patients With Unstable Angina
}

\author{
Saeed Alipour Parsa ${ }^{1}$, Isa Khaheshi ${ }^{1, *}$; Mohammad Parsa \\ Mahjoob $^{1}$; Mohammad Ali Akbarzadeh ${ }^{1}$; Shooka Esmaeeli ${ }^{2}$ \\ ${ }^{1}$ Cardiovascular Research Center, Modarres Hospital, Shahid Beheshti University \\ of Medical Sciences, Tehran, Iran \\ ${ }^{2}$ Student's Scientific Research Center (SSRC), Tehran University of Medical \\ Sciences, Tehran, Iran \\ * Corresponding author: Isa Khaheshi, Cardiovascular Research Center, Modarres \\ Hospital, Shahid Beheshti University of Medical Sciences, Tehran, Iran. Tel: +98- \\ 2122074087, Fax: +98-2122074101.Email: isa_khaheshi@yahoo.com
}

DOI: $10.20286 / \mathrm{ijcp}-010103$

Submited: 01.09.2015

Accepted: 20.09.2015

\section{Keywords:}

Hemoglobin A, Glycosylated

Diabetes Mellitus

Angina Pectoris

Patient Admission

(C) 2016. International Journal of

Cardiovascular Practice.

\begin{abstract}
Introduction: There have been incompatible evidences about the prognostic value of $\mathrm{HbAlc}$ on the adverse outcomes in acute coronary syndrome. Also, these data are so limited in nondiabetic patients with unstable angina.

Methods: In this cross-sectional study, HbAlc level of 231 nondiabetic patients admitted with unstable angina, was measured using high performance liquid affinity chromatography (HPLC) at admission. Then transthoracic echocardiography (TTE) was performed for evaluation of ejection fraction (EF) using Simpson method.

Results: Our data revealed that $\mathrm{HbAlc}$ was significantly higher in patients with $\mathrm{EF} \leq 50 \%$ in comparison with $\mathrm{EF}>50 \%$ group ( $\mathrm{P}$ value $=0.01$ ).

Conclusions: $\mathrm{HbAlc}$ may be a helpful prognostic marker in nondiabetic patients admitted in emergency department with diagnosis of unstable angina.
\end{abstract}

\section{INTRODUCTION}

Higher level of Glycated hemoglobin Alc (HbAlc) as a marker of chronic glucose dysregulation and accelerated atherosclerosis has been shown to be a prognostic factor in cardiovascular disease and congestive heart failure. Moreover, $\mathrm{HbAlc}$ has been suggested as a marker of adverse outcomes in the setting of acute coronary syndromes [1$5]$. Stress induced hyperglycemia even in non-diabetics, is related with enhanced activation of stress responsive kinases and initiation of apoptosis and cardiac cell necrosis, which sequentially results in systolic and diastolic dysfunction $[6,7]$.

Although an association between $\mathrm{HbAlc}$ level and adverse outcomes has been explained in diabetic patients with acute coronary syndromes, there are limited data in nondiabetic patients with unstable angina [8].

Therefore, the primary objective of this study was to determine the association of $\mathrm{HbAlc}$ levels at admission and ejection fraction (EF) in nondiabetic patients with unstable angina.

\section{METHODS}

This was a cross-sectional study conducted from April 2013 to March 2014 on patients admitted in coronary chest pain unit of Modarres hospital. Those nondiabetic patients diagnosed with unstable angina were selected. The exclusion criteria were documented diabetes mellitus, ST elevation
MI (STEMI), None-ST elevation MI (NSTEMI), HbA1c $\geq 6.5 \%$ or Lab test indicative of diabetes mellitus, history of definite MI, history of congestive heart failure and history of chronic kidney disease.

For each patient with diagnosis of unstable angina [9], HbAlc level was determined using high performance liquid affinity chromatography (HPLC) at admission. Then transthoracic echocardiography (TTE) was performed to evaluate EF using the Simpson method. Finally, patients were divided into two groups including $\mathrm{EF}>50 \%$ and $\mathrm{EF} \leq 50 \%$. The Institutional Review Board approved the study protocol and patients provided informed written consent. Statistical analyses were performed by SPSS statistical software (version 16). Independent sample T-test was used for quantitative studies. $\mathrm{P}$ value $<0.05$ was considered statistically significant.

\section{RESULTS}

In total, 231 patients including 122 males and 109 females, with diagnosis of unstable angina entered the study. Mean age of patients was $57.1 \pm 4.5$ years. 130 patients had $\mathrm{EF} \leq$ $50 \%$ and 101 patients EF > 50\%. The mean level of HbAlc was $5.1 \% \pm 0.43 \%$ for all patients. Mean level of $\mathrm{HbAlc}$ was $5.9 \% \pm 0.51 \%$ for $\mathrm{EF} \leq 50 \%$ group and $4.2 \% \pm 0.37 \%$ for $\mathrm{EF}$ $>50 \%$ group. Data analysis revealed that HbAlc was significantly higher in patients with $\mathrm{EF} \leq 50 \%$ in comparison with $\mathrm{EF}>50 \%$ group $(\mathrm{P}$ value $=0.01)$. Table 1 shows demographic and biochemical data of the two groups. 


\begin{tabular}{|c|c|c|}
\hline & $\mathrm{EF} \leq 50 \%$ group, $N=122$ & $\mathrm{EF}>50 \%$ group, $N=109$ \\
\hline Age & $59.2 \pm 3.3$ & $55 \pm 5.8$ \\
\hline \multicolumn{3}{|l|}{ Gender } \\
\hline Male & $63(51.6 \%)$ & $59(54.1 \%)$ \\
\hline Female & $59(48.4 \%)$ & $50(45.9 \%)$ \\
\hline HbA1c level, \% & $5.9 \pm 0.51$ & $4.2 \pm 0.37$ \\
\hline
\end{tabular}

Data in table are presented as Mean \pm SD or No. (\%)

\section{DISCUSSION}

The key finding of the current study was that HbAlc level at admission is considerably related with reduced ejection fraction in diagnosed nondiabetic patients with unstable angina. Previous studies showed that enhanced $\mathrm{HbAlc}$ is related with higher cardiovascular risk in patients with and without diabetes $[8,10]$.

Another study on 50 patients with acute coronary syndrome including unstable angina, NSTEMI and STEMI determined that $\mathrm{HbAlc}$ at admission is a strong predictor of LV systolic dysfunction as a main adverse event of acute coronary syndrome in patients not known to be diabetics [11].

Measurement of glycated forms of hemoglobin presents a trustworthy reflection of the level of general glucometabolic status in the prior 8-12 weeks. It can be considered as an indicator for diabetic control. There have been inconsistent evidences about the prognostic value of $\mathrm{HbAlc}$ on adverse outcomes in acute coronary syndrome [3-5].

In a study performed in Asian Indians with normal glucose tolerance, a strong correlation of $\mathrm{HbAlc}$ and cardiovascular risk factors was established. Normal glucose tolerance patients with three or more metabolic abnormalities had the highest $\mathrm{HbAlc}$ levels and an $\mathrm{HbA1c}$ cut off point of $\geq 6.5 \%$ was found to be effective in predicting both metabolic syndrome and coronary artery disease $[12,13]$.

Our study focused only on patients with unstable angina and those with STEMI and NSTEMI were excluded. The study results emphasized on relation between $\mathrm{HbAlc}$ level as a marker of accelerated atherosclerosis and reduced EF on TTE in nondiabetic unstable angina patients. Moreover, another investigation showed $\mathrm{HbAlc}$ level as a predictor of fatal and nonfatal cardiovascular events in nondiabetic peritoneal dialysis patients [14].

On the other hand, one study suggested that HbAlc levels before admission are not related with short-term cardiovascular outcome in diabetic patients admitted with acute coronary syndrome [15]. This study can serve as a trigger for future investigations evaluating association of $\mathrm{HbAlc}$ and adverse outcomes in nondiabetic patients with unstable angina and developing new prognostic algorithm and cut off points for $\mathrm{HbA1} \mathrm{c}$ in diabetic and nondiabetic patients with unstable angina.

Our study showed that $\mathrm{HbAlc}$ in unstable angina was considerably higher in nondiabetic patients with $\mathrm{EF} \leq 50 \%$ in comparison with EF $>50 \%$ group. This finding emphasizes this point that $\mathrm{HbAlc}$ may be a helpful prognostic marker in nondiabetic patients admitted in emergency departments with unstable angina. Nevertheless, detailed data about the prognostic role of $\mathrm{HbAlc}$ is to somehow controversial, and this study with such a relatively small size cannot clarify all the remaining doubts.

\section{ACKNOWLEDGMENTS}

There is no acknowledgment for the present study.

\section{CONFLICT OF INTEREST}

Authors declare that they have no conflict of interest.

\section{REFERENCES}

1. Lynch M, Gammage MD, Lamb P, Nattrass M, Pentecost BL. Acute myocardial infarction in diabetic patients in the thrombolytic era. Diabet Med. 1994;11:162-5. http://www.ncbi.nlm.nih.gov/ pubmed/8200200

2. Bauters C, Ennezat PV, Tricot O, Lauwerier B, Lallemant R, Saadouni $\mathrm{H}$, et al. Stress hyperglycaemia is an independent predictor of left ventricular remodelling after first anterior myocardial infarction in non-diabetic patients. Europe Heart J. 2007;28:546-52.

3. Cakmak M, Cakmak N, Cetemen S, Tanriverdi H, Enc Y, Teskin O, et al. The value of admission glycosylated hemoglobin level in patients with acute myocardial infarction. Can J Cardiol. 2008;24:375-8. http:// www.ncbi.nlm.nih.gov/pubmed/18464942

4. Oswald G, Yudkin JS. Prognostic value of admission plasma glucose and $\mathrm{HbA}$ in acute myocardial infarction. Diabet Med. 2005;22:509-10; author reply 10. http://www.ncbi.nlm.nih.gov/pubmed/15787683

5. Timmer JR, Ottervanger JP, Bilo HJ, Dambrink JH, Miedema K, Hoorntje JC, et al. Prognostic value of admission glucose and glycosylated haemoglobin levels in acute coronary syndromes. QJM. 2006;99:23743. http://www.ncbi.nlm.nih.gov/pubmed/16504985

6. Webster KA. Stress hyperglycemia and enhanced sensitivity to myocardial infarction. Curr Hypertens Rep. 2008;10:78-84. http://www. ncbi.nlm.nih.gov/pubmed/18367031

7. Cai L, Li W, Wang G, Guo L, Jiang Y, Kang YJ. Hyperglycemia-induced apoptosis in mouse myocardium: mitochondrial cytochrome C-mediated caspase-3 activation pathway. Diabetes. 2002;51:1938-48. http:// www.ncbi.nlm.nih.gov/pubmed/12031984

8. Selvin E, Marinopoulos S, Berkenblit G, Rami T, Brancati FL, Powe NR, et al. Meta-analysis: glycosylated hemoglobin and cardiovascular disease in diabetes mellitus. Ann Intern Med. 2004;141:421-31. http:// www.ncbi.nlm.nih.gov/pubmed/15381515

9. Scirica BM, Cannon CP, McCabe CH, Murphy SA, Anderson HV, Rogers WJ, et al. Prognosis in the thrombolysis in myocardial ischemia III registry according to the Braunwald unstable angina pectoris classification. Am J Cardiol. 2002;90:821-6. http://www.ncbi.nlm.nih.gov/ pubmed/12372567

10. Khaw KT, Wareham N, Bingham S, Luben R, Welch A, Day N. Association of hemoglobin Alc with cardiovascular disease and mortality in adults: the European prospective investigation into cancer in Norfolk. Ann Intern Med. 2004;141:413-20. http://www.ncbi.nlm.nih.gov/ pubmed/15381514

11. Timmer JR, Hoekstra M, Nijsten MW, van der Horst IC, Ottervanger 
JP, Slingerland RJ, et al. Prognostic value of admission glycosylated hemoglobin and glucose in nondiabetic patients with ST-segment-elevation myocardial infarction treated with percutaneous coronary intervention. Circulation. 2011;124:704-11. http://www.ncbi.nlm.nih. gov/pubmed/21768543

12. Stolar M. Glycemic control and complications in type 2 diabetes mellitus. Am J Med. 2010;123:S3-11. http://www.ncbi.nlm.nih.gov/ pubmed/20206730

13. Laakso M. Dyslipidemia, morbidity, and mortality in non-insulin-dependent diabetes mellitus. Lipoproteins and coronary heart disease in non-insulin-dependent diabetes mellitus. J Diabetes Complications. 1997;11:137-41. http://www.ncbi.nlm.nih.gov/pubmed/9101400

14. Dheir H, Ozkahya M, Kircelli F, Sezis Demirci M,Asci G, TozH, et al. Glycosylated hemoglobin levels are associated with cardiovascular events in nondiabetic peritoneal dialysis patients. J Nephrol. 2012;25:107-12. http://www.ncbi.nlm.nih.gov/pubmed/21607914

15. Chan CY, Li R, Chan JY, Zhang Q, Chan CP, Dong M, et al. The value of admission $\mathrm{HbA}(1 \mathrm{c})$ level in diabetic patients with acute coronary syndrome. Clin Cardiol. 2011;34:507-12. http://www.ncbi.nlm.nih. $\mathrm{gov} / \mathrm{pubmed} / 21717470$ 